Glosses

Studia Iuridica Lublinensia vol. XXIX, 1, 2020

DOI: 10.17951/sil.2020.29.1.261-271

\title{
Joanna Bodio
}

Uniwersytet Marii Curie-Skłodowskiej w Lublinie, Polska

ORCID: 0000-0003-0428-7267

joanna.bodio@poczta.umcs.lublin.pl

\section{Warunki udzielania przez sąd pouczeń na \\ podstawie art. 5 k.p.c. Glosa do wyroku \\ Sądu Najwyższego z dnia 27 lutego 2019 r. (II PK 307/17, LEX nr 2626246)}

\author{
Conditions for Giving Instructions by the Court Pursuant to Article 5 \\ of the Code of Civil Procedure. Gloss to the Judgement of the \\ Supreme Court of 27 February 2019 (II PK 307/17, \\ LEX No. 2626246)
}

\section{STRESZCZENIE}

Autorka podziela stanowisko Sądu Najwyższego, że udzielanie przez sąd pouczeń, o których mowa w art. 5 k.p.c., powinno mieć charakter wyjątkowy i zależeć od oceny i uznania sądu uwiarygodnionego konkretną sytuacją procesową. Udzielanie przez sąd pouczeń determinowane jest uzasadnioną potrzebą i niezbędnym charakterem pouczeń. Ma ono miejsce wówczas, gdy zachodzi potrzeba zapobieżenia nierówności podmiotów toczącego się postępowania w kontekście zasady równości stron, a więc gdy strona z uwagi na swoją nieporadność i stopień skomplikowania sprawy nie jest w stanie ani zrozumieć istoty prowadzonego postępowania, ani podjąć stosownych czynności procesowych.

Słowa kluczowe: udzielanie przez sąd pouczeń; uzasadniona potrzeba procesowa; zasada równości stron

Jak stwierdził Sąd Najwyższy w wyroku z dnia 27 lutego 2019 r. (II PK 307/17):

[...] udzielenie pouczenia zależy od oceny i uznania sądu uwiarygodnionego konkretną sytuacją procesową i staje się powinnością sądu tylko w sytuacjach zupełnie wyjątkowych, kiedy zachodzi potrzeba zapobieżenia nierówności podmiotów toczącego się postępowania, a więc wówczas, gdy strona z uwagi na swoją nieporadność i stopień skomplikowania sprawy nie jest w stanie zrozumieć istoty prowadzonego postępowania i podjąć w związku z tym stosowne czynności procesowe. 
Teza Sądu Najwyższego jest słuszna i potwierdza ustaloną w tym zakresie linię orzecznictwa ${ }^{1}$. Otrzymanie od sądu niezbędnych pouczeń co do czynności procesowych przestało być zatem prawem strony przysługującym jej w każdym przypadku, gdy nie jest ona reprezentowana przez zawodowego pełnomocnika (adwokata, radcę prawnego ${ }^{2}$, rzecznika patentowego lub Prokuratorię Generalną Rzeczypospolitej Polskiej), a stało się możliwością determinowaną uzasadnioną potrzebą procesową ${ }^{3}$ i niezbędnym charakterem pouczeń ${ }^{4}$. Uzasadnienie Sądu Najwyższego wymaga uzupełnienia o dwie ważne kwestie, które wiążą się z zagadnieniem udzielania przez sąd pouczeń. Dotyczą one doprecyzowania terminów „uzasadniona potrzeba” i „niezbędne pouczenia”, którymi posługuje się art. 5 k.p.c., oraz wskazania kryteriów udzielania przez sąd pouczeń w kontekście zasady równości stron.

Rozważając pierwsze z wymienionych zagadnień, należy wskazać, że Kodeks postępowania cywilnego nie zawiera ustawowej definicji pojęć „uzasadniona potrzeba" i „niezbędne pouczenia". Wykładnię pojęć, o których mowa w art. 5 k.p.c., pozostawiono w gestii organu procesowego, któremu ustawodawca dał duży margines swobody, wychodząc z założenia, że sztywne wskazanie okoliczności, od których zaistnienia byłoby uzależnione dokonanie takich pouczeń, nie spełni celu tej regulacji ${ }^{5}$. Sąd (przewodniczący) każdorazowo musi ustalić, czy w danych okolicznościach można mówić o „uzasadnionej potrzebie” oraz czy udzielane pouczenia mają charakter „niezbędny”. Chodzi tu o niezbędność pouczenia pod kątem zarówno jego celowości, jak i treści. Z jednej strony sąd może udzielać pouczeń, które są niezbędne dla zapewnienia dalszego prawidłowego biegu postępowania, z drugiej zaś powinien ograniczyć pouczenie do wskazania zasadniczych informacji co do danej czynności procesowej ${ }^{7}$.

1 Wyrok SN z dnia 27 lutego 2019 r., II PK 307/17, LEX nr 2626246; postanowienie SN z dnia 24 stycznia 2019 r., I UK 5/18, Legalis nr 1866676; postanowienie SN z dnia 15 stycznia 2019 r., II UZ 35/18, Legalis nr 1865721; wyrok SN z dnia 17 kwietnia 2018 r., I PK 30/17, LEX nr 2558421; wyrok SN z dnia 6 kwietnia 2017 r., II UK 112/16, LEX nr 2298299; wyrok SN z dnia 27 lutego 2014 r., II PK 134/13, LEX nr 1455113; wyrok SN z dnia 21 marca 2018 r., II UK 231/17, LEX nr 2490054.

2 M. Manowska, Zmiany w kodeksie postępowania cywilnego wprowadzone w 2004 r., „Przegląd Sądowy" 2005, nr 4, s. 5.

3 P. Feliga, [w:] Kodeks postępowania cywilnego. Komentarz, t. 1: Art. 1-505 $5^{39}$, red. T. Szanciło, Legalis 2019, art. 5, $\mathrm{Nb} 5$.

4 M. Uliasz, Kodeks postepowania cywilnego. Komentarz, Legalis 2008, art. 5, Nb 9.

5 P. Rylski, Działanie sądu z urzędu a podstawa faktyczna wyroku cywilnego, Warszawa 2009, s. 234 .

6 Ibidem.

7 M. Uliasz, op. cit., art. 5, Nb 8. O zakresie pouczenia strony „,niezastępowanej” przez zawodowego pełnomocnika stanowi m.in. art. $210 \S 2^{1}$ k.p.c. (wskazuje przepisy art. $162 \S 1$, art. $205^{12}$ $\S 2$, art. 229 i art. 230 k.p.c., tj. związane z odpowiednim i sprawnym gromadzeniem materiału procesowego) i art. 327 k.p.c. (dotyczy pouczeń związanych ze sporządzaniem i wnoszeniem środków zaskarżenia). Por. T. Zembrzuski, Pouczanie strony występujacej w procesie cywilnym bez zawodowego petnomocnika co do wnoszenia środków zaskarżenia, [w:] Ochrona strony słabszej stosunku 
Niezbędność dokonywania pouczeń bywa wiązana z ryzykiem pozbawienia strony wpływu na przebieg postępowania i uniemożliwieniem jej realizacji przysługujących uprawnień ${ }^{8}$, jak również ze stopniem skomplikowania spraw przekraczających umiejętności i możliwości obrony swych praw przez stronę9. W literaturze i orzecznictwie wśród kryteriów uzasadniających skorzystanie przez sąd z możliwości udzielania pouczeń wskazuje się na „rażącą bezradność strony”10, jej „nieporadność” ${ }^{11}$, niedostateczną znajomość prawa ${ }^{12}$ lub przeciwdziałanie nieuzasadnionej bezczynności strony procesowej ${ }^{13}$. Nie wydaje się natomiast, by obecnie jedyną podstawą do udzielenia pouczeń, o których mowa w art. 5 k.p.c., był brak należytej wiedzy prawnej strony, jeżeli nie można o niej powiedzieć, że jest osobą

prawnego. Księga jubileuszowa ofiarowana Profesorowi Adamowi Zielińskiemu, red. M. Boratyńska, Warszawa 2016, s. 848.

${ }^{8}$ Wyrok SN z dnia 30 czerwca 1999 r., II UKN 21/99, OSNAP 2000, nr 18, poz. 695. W doktrynie uważa się, że sąd powinien udzielać pouczeń tylko „w przypadkach skrajnej nieporadności strony", a nawet postuluje się uchylenie art. 5 k.p.c. Zob. M.M. Cieśliński, W kwestii stosowania art. 5 k.p.c., „Przegląd Sądowy” 1999, nr 4, s. 107-108; A.G. Harla, Udzielanie przez sąd stronom i uczestnikom postępowania cywilnego wskazówek w świetle art. 5 k.p.c. (uwagi de lege lata i de lege ferenda), „Przegląd Sądowy” 2003, nr 10, s. 107; A. Góra-Błaszczykowska, Zasada równości stron $w$ aspekcie zmiany przepisów art. 5 i 212 k.p.c. $i$ wynikających z nich obowiązków sq̨du w postępowaniu cywilnym (uwagi na tle orzecznictwa Sądu Najwyższego), „Przegląd Sądowy” 2005, nr 10, s. 95; J. Bodio, [w:] Kodeks postępowania cywilnego. Komentarz do zmian 2019, t. 1: Koszty sadowe w sprawach cywilnych. Dochodzenie roszczeń w postępowaniu grupowym. Przepisy przejściowe, red. T. Zembrzuski, Warszawa 2020, s. 58.

9 Podobnym zakresem zostały objęte pouczenia, jakich może udzielać przewodniczący w toku prowadzenia rozpraw. Zob. H. Pietrzkowski, Czynności procesowe zawodowego petnomocnika w sprawach cywilnych, Warszawa 2017, s. 264; T. Zembrzuski, op. cit., s. 849; H. Dolecki, [w:] Kodeks postępowania cywilnego. Komentarz, t. 1: Artykuty 1-366, red. H. Dolecki, T. Wiśniewski, LEX/el. 2013, art. 5, Nb 4; wyrok SN z dnia 13 maja 1997 r., II UKN 100/97, OSNP 1998, nr 4, poz. 133; wyrok SN z dnia 16 września 1998 r., II UKN 214/98, OSNP 1999, nr 18, poz. 593; wyrok SN z dnia 13 lipca 2000 r., II UKN 639/99, OSNP 2000, nr 3, poz. 78; wyrok SN z dnia 11 czerwca 2013 r., II UK 389/12, OSNP 2014, nr 3, poz. 48; wyrok SA w Warszawie z dnia 24 stycznia 2014 r., VI ACa 1240/13, LEX nr 1506315.

${ }^{10}$ M.M. Cieśliński, op. cit., s. 105.

11 M. Sawczuk, Niezawisłość sędziowska a granice pomocy stronie, [w:] Studia z procesu cywilnego, red. K. Korzan, Katowice 1986, s. 42; S. Dalka, Rola i zadania art. 5 k.p.c., „Przegląd Prawa Egzekucyjnego" 2005, nr 7-9, s. 8 (podaję za: P. Rylski, Działanie sadu..., s. 234); wyrok SA w Gdańsku z dnia 2 lutego 2016 r., III AUa 1457/15, LEX nr 2012865; wyrok SA w Katowicach z dnia 22 kwietnia 2015 r., V ACa 762/14, LEX nr 1682851; wyrok SN z dnia 4 kwietnia 2014 r., I UK 363/13, LEX nr 1482341; wyrok SN z dnia 11 października 2013 r., III UK 139/12, LEX nr 1463907; postanowienie SN dnia 27 czerwca 2013 r., III CZ 33/13, LEX nr 1360264; wyrok SN z dnia 18 sierpnia 2009 r., I UK 74/09, LEX nr 530693.

12 Postanowienie SN z dnia 10 stycznia 2012 r., I UK 289/11, LEX nr 1215783.

13 J. Mokry, Aktywność informacyjna sądu a realizacja praw i obowiązów procesowych przez strony procesu cywilnego, [w:] Proces i prawo. Rozprawy prawnicze. Ksiega pamiątkowa ku czci Profesora Jerzego Jodtowskiego, Wrocław 1989, s. 429 (podaję za : P. Rylski, Działanie sądu..., s. 234). 
nieporadną ${ }^{14}$. Osoba o pełnej zdolności do czynności prawnych ma pełną zdolność do występowania w postępowaniu sądowym i posiada możliwość samodzielnego dokonywania czynności procesowych ${ }^{15}$. Jej nieporadność, wynikająca z braku orientacji w przepisach regulujących postępowanie, może uzasadniać dokonywanie przez sąd odpowiednich pouczeń, jednak potrzeba taka nie występuje, jeżeli strona składa w toku postępowania wypowiedzi i pisma niewzbudzające wątpliwości co do ich sensu ${ }^{16}$. Stanowisko to potwierdził Sąd Najwyższy w glosowanym orzeczeniu, zwracając uwagę na to, że strona podejmowała świadomie, prawidłowo i skutecznie czynności procesowe $\mathrm{w}$ toku procesu oraz sporządzała samodzielnie pisma procesowe $\mathrm{z}$ powołaniem się na konkretne przepisy prawa (w tym prawa międzynarodowego) i poglądy doktryny, co wskazuje na jej ponadprzeciętną świadomość prawną ${ }^{17}$. Samodzielne występowanie strony w procesie oraz brak wykształcenia prawniczego nie świadczą o nieporadności strony i nie uzasadniają konieczności udzielania pouczeń. Pouczenia są więc zbędne, jeśli strona mimo braku profesjonalnego zastępstwa dobrze radzi sobie z prowadzeniem własnej sprawy lub z obroną ${ }^{18}$.

Udzielanie przez sąd pouczeń wchodzi więc w grę w razie nieporadności strony, pojmowanej jako nieumiejętność korzystania z przysługujących stronie praw procesowych, oraz spełnienia nałożonych na nią obowiązków ${ }^{19}$. Nieporadność strony może mieć źródło we właściwościach psychicznych, fizycznych lub intelektualnych. Powinna ona przejawiać się w jej specyficznych cechach, powodujących trudności w formułowaniu żądań i wniosków, sporządzaniu pism spełniających wymogi proceduralne czy przedstawianiu racji i obrony swych interesów w toku procesu ${ }^{20}$. Stwierdzenie, że nieporadność strony jest tak duża, iż nie pozwala na samodzielne

14 P. Rylski, Działanie sądu..., s. 234.

15 Zdolność procesowa należy do kwalifikacji podmiotowych strony. Zob. m.in. Ł. Błaszczak, E. Marszałkowska-Krześ, Przymioty procesowe stron i uczestników postępowania nieprocesowego niezbędne do dochodzenia ochrony prawnej na drodze sadowej. Wybrane zagadnienia, „Studia Prawno-Ekonomiczne" 2015, t. 95, s. 11-13; Ł. Błaszczak, Wadliwość czynności procesowych stron i uczestników. Obecny model i propozycja zmian w przyszłym Kodeksie postepowania cywilnego, [w:] Postępowanie rozpoznawcze w przyszłym Kodeksie postępowania cywilnego. Materiały Ogólnopolskiego Zjazdu Katedr i Zakładów Postępowania Cywilnego w Katowicach-Kocierzu (26-29 września 2013 r.), red. K. Markiewicz, A. Torbus, Warszawa 2014, s. 205-206; P. Rylski, Uczestnik postepowania nieprocesowego-zagadnienia konstrukcyjne, Warszawa 2017, s. 219; J. Bodio, Status dziecka jako uczestnika postępowania nieprocesowego, Warszawa 2019, s. 242.

16 Wyrok SN z dnia 3 sierpnia 2006 r., II UK 258/05, Legalis nr 303358.

${ }_{17}$ Uzasadnienie wyroku SN z dnia 27 lutego 2019 r., II PK 307/17, LEX nr 2626246.

18 A. Góra-Błaszczykowska, [w:] Kodeks postepowania cywilnego, t. I A: Komentarz. Art. $1-424^{12}$, red. A. Góra-Błaszczykowska, Legalis 2020, art. 5, Nb 8.

19 B. Dobrzański, Glosa do orzeczenia SN z dnia 20.01.1966 r., II PR 37/65, „Nowe Prawo” 1966, nr 11, s. 1450-1451 (podaję za: P. Osowy, Aktywność informacyjna sądu a ustawowe granice pomocy stronie - rozważania na tle art. 5 k.p.c., „Rejent” 2003, nr 7-8, s. 120-121).

20 A. Łazarska, Rzetelny proces cywilny, Warszawa 2012, s. 438-439. 
wykorzystanie udzielanych pouczeń, powinno prowadzić do zwrócenia stronie uwagi na potrzebę skorzystania z fachowej pomocy oraz do wyjaśnienia zasad uzyskania takiej pomocy z urzędu ${ }^{21}$. Chodzi przy tym o taką nieporadność strony, która powoduje, że brak pouczenia prowadziłby do naruszenia jej gwarancji procesowych do sprawiedliwego rozpatrzenia sprawy przez naruszenie zasady równości stron ${ }^{22}$.

Uzasadniona potrzeba udzielania pouczeń ma miejsce, gdyby działanie lub zaniechanie strony spowodowało ujemne dla niej skutki prawne ${ }^{23}$, gdy z powodu ułomności strona nie wykazuje w postępowaniu aktywności, a w szczególności nie rozumie swojej sytuacji procesowej i nie podejmuje działań mających na celu obronę swoich praw ${ }^{24}$, lub gdy stroną samodzielnie występującą w procesie jest osoba głęboko upośledzona umysłowo, u której ciężka choroba psychiczna nie tylko utrudnia, lecz wręcz uniemożliwia świadome i celowe działanie w procesie ${ }^{25}$. Należy podkreślić, że nie każda choroba psychiczna czy inne zaburzenia psychiczne strony (która jednak nie jest ubezwłasnowolniona) stwarzają obowiązek udzielania pouczeń. Sąd nie ma takiego obowiązku, jeżeli strona mimo choroby psychicznej dobrze radzi sobie z prowadzeniem swych spraw przed sądem ${ }^{26}$.

Biorąc pod uwagę wskazane kryteria, sąd powinien stwarzać stronom równe szanse procesowe, wyrównując występującą nieporadność strony i nieznajomość norm procesowych. Możliwość udzielania stronom i uczestnikom postępowania przez sąd pouczeń co do czynności procesowych stanowi bowiem realizację zasady równości stron ${ }^{27}$. Przez zasadę równości stron rozumie się w doktrynie konieczność posiadania przez występujące $\mathrm{w}$ nim przeciwstawne strony równych praw procesowych i gwarancji jednakowej możliwości obrony swoich interesów ${ }^{28}$. Daje ona każdej ze stron takie same możliwości działania i korzystania z takich samych środków obrony swych praw przy uwzględnieniu specyfiki każdej ze stron postę-

${ }^{21}$ Postanowienie SN z dnia 2 lipca 2009 r., V CSK 481/08, LEX nr 627260; wyrok SN z dnia 4 kwietnia 2014 r., I UK 363/13, LEX nr 1482341.

22 Wyrok SA w Gdańsku z dnia 22 marca 2018 r., III AUa 1402/17, LEX nr 2514384.

${ }^{23}$ Wyrok SN z dnia 13 maja 1997 r., II UKN 100/97, OSNAP 1998, nr 4, poz. 133.

${ }^{24}$ Wyrok SN z dnia 18 sierpnia 2009 r., I UK 74/09, LEX nr 530693; wyrok SN z dnia 30 czerwca 2010 r., V CSK 1/10, LEX nr 677906; postanowienie SN z dnia 27 września 2012 r., III CSK 13/12, LEX nr 1224681; postanowienie SN z dnia 27 czerwca 2013 r., III CZ 33/13, LEX nr 1360264; postanowienie SN z dnia 28 września 1999 r., II CKN 269/99, LEX nr 39112; J. Misztal-Konecka, O udziale w postępowaniu cywilnym osób, które doznaja przeszkód w osobistym dokonywaniu czynności procesowych, „Przegląd Sądowy” 2017, nr 11-12, s. 130.

${ }_{25}$ Wyrok SA w Lublinie z dnia 30 marca 2017 r., III AUa 1115/16, LEX nr 2274274.

26 A. Góra-Błaszczykowska, [w:] Kodeks postępowania..., art. 5, Nb 8.

${ }^{27}$ Eadem, Zasada równości stron w aspekcie zmiany przepisów..., s. 86.

${ }_{28}$ T. Ereciński, K. Weitz, Prawda i równość stron w postępowaniu cywilnym a orzecznictwo Trybunału Konstytucyjnego, [w:] Orzecznictwo Trybunału Konstytucyjnego a Kodeks postępowania cywilnego. Materiały Ogólnopolskiego Zjazdu Katedr i Zakładów Postępowania Cywilnego. Serock k. Warszawy, 24-26 września 2009 r., red. T. Ereciński, K. Weitz, Warszawa 2010, s. 47. 
powania, a także umożliwia skorzystanie z prawa do wysłuchania i wypowiedzenia się co do twierdzeń strony przeciwnej ${ }^{29}$. Zasada ta przejawia się m.in. w tym, by sąd stosował przepisy proceduralne bez naruszania równowagi między prawami i obowiązkami procesowymi $\operatorname{stron}^{30}$.

Możliwość udzielania pouczeń jest wyrazem konstytucyjnie dopuszczalnego „uprzywilejowania wyrównawczego”, zmierzającego do faktycznego zrównania procesowych możliwości stron, niezależnie od tego, czy są one reprezentowane przez adwokata (radcę prawnego), czy występują w sprawie samodzielnie ${ }^{31}$. Udzielenie pouczeń nie może prowadzić ani do uprzywilejowania, ani do pokrzywdzenia strony w procesie. Sąd może korzystać z tego uprawnienia tylko w wyjątkowych sytuacjach, wyczerpując kryteria wskazane w art. 5 k.p.c. ${ }^{32}$ Powinien więc indywidualnie oceniać możliwość udzielania stronie pouczeń, biorąc pod uwagę specyfikę konkretnej sprawy, cechy i możliwości intelektualne strony (determinowane jej wiekiem, inteligencją, stanem zdrowia i wykształceniem) ${ }^{33}$ konieczne do uczestniczenia $\mathrm{w}$ procesie $\mathrm{w}$ sposób nienaruszający zasady równości, jak również możliwość umożliwienia stronie wypowiedzenia się co do przedmiotu sprawy i stanowiska jej przeciwnika procesowego ${ }^{34}$. Ponadto powinien brać pod uwagę sposób zachowania się stron ${ }^{35}$. Dopiero ocena wszystkich wskazanych kryteriów pozwala sądowi na realizację wynikającego z art. 5 k.p.c. uprawnienia do udzielania niezbędnych pouczeń $\mathrm{w}$ razie uzasadnionej potrzeby.

Udzielanie stronom niezbędnych pouczeń umożliwia wskazanie obowiązywania regulacji prawnych, których zastosowanie lub pominięcie może wiązać się z negatywnymi konsekwencjami procesowymi ${ }^{36}$, a co za tym idzie ma na celu uniknięcie ujemnych skutków nieporadności strony, czyli wyrównanie gorszej pozycji faktycznej

29 A. Góra-Błaszczykowska, Zasada równości stron w procesie cywilnym, Warszawa 2008, s. 2.

30 Ibidem.

31 P. Pogonowski, Realizacja prawa do sądu w postępowaniu cywilnym, Warszawa 2005, s. 72.

32 A. Góra-Błaszczykowska, Zasada równości stron $w$ aspekcie zmiany przepisów..., s. 95.

33 Ibidem, s. 96; eadem, Zasada równości stron w procesie..., s. 180; J. Derlatka, Wyłączenie sędziego w postepowaniu cywilnym, Warszawa 2016, s. 309-310; A. Marciniak, [w:] Kodeks postepowania cywilnego, t. 1: Komentarz. Art. 1-205, red. A. Marciniak, Legalis 2019, art. 5, Nb 3; T. Zembrzuski, op. cit., s. 849-850; wyrok SA w Gdańsku z dnia 2 lutego 2016 r., III AUa 1457/15, LEX nr 2012865; wyrok SA w Warszawie z dnia 6 listopada 2012 r., I ACa 510/12, LEX nr 124693; postanowienie SN z dnia 2 lipca 2009 r., V CSK 481/08, LEX nr 627260.

34 J. Studzińska, Prawo czy konieczność posiadania pelnomocnika profesjonalnego dla ochrony strony słabszej w postepowaniu cywilnym. Kilka uwag praktycznych, [w:] Ochrona strony słabszej stosunku prawnego..., s. 825.

35 A. Góra-Błaszczykowska, Zasada równości stron $w$ aspekcie zmiany przepisów..., s. 96; eadem, Zasada równości stron w procesie..., s. 180; J. Derlatka, op. cit., s. 309-310; A. Marciniak, op. cit., art. 5, Nb 3; T. Zembrzuski, op. cit., s. 849-850; wyrok SA w Gdańsku z dnia 2 lutego 2016 r., III AUa 1457/15, LEX nr 2012865; wyrok SA w Warszawie z dnia 6 listopada 2012 r., I ACa 510/12, LEX nr 124693; postanowienie SN z dnia 2 lipca 2009 r., V CSK 481/08, LEX nr 627260.

36 T. Zembrzuski, op. cit., s. 846. 
strony słabszej ${ }^{37}$. Nieporadność strony wiązana jest bowiem często z pojęciem „strony słabszej procesu". Pod tym terminem rozumie się stronę niezaradną, niezorientowaną w zawiłościach jurydycznych, podmiot, który ze względu na brak odpowiedniego wykształcenia nie jest w stanie skutecznie bronić swoich praw bądź samodzielnie prowadzić procesu, a jednocześnie nie stać go na profesjonalnego pełnomocnika ${ }^{38}$.

Racjonalne wspieranie przez sąd strony słabszej polega m.in. na zapewnieniu jej swoistego „przywileju informacyjnego”, który ma służyć zapobieżeniu faktycznej nierówności stron przez utrzymanie równowagi sił między uczestnikami postępowania sądowego ${ }^{39}$ zastępowanymi i niezastępowanymi przez zawodowego pełnomocnika. Ów „przywilej informacyjny” powinien sprowadzać się do przekazywania stronie słabszej odpowiedniej ,wiedzy, wiadomości, informacji czy zaleceń" na temat obowiązujących przepisów Kodeksu postępowania cywilne$\mathrm{go}^{40}$, przy czym pouczenie musi być adekwatne do jej zdolności percepcyjnych, a w wypadku stwierdzenia, że nieporadność strony jest na tyle duża, iż nie pozwala na samodzielne wykorzystanie udzielanych jej wskazówek, sąd powinien zwrócić stronie uwagę na możliwość skorzystania z fachowej pomocy prawnej i wyjaśnić zasady uzyskania takiej pomocy z urzędu ${ }^{41}$. Z przepisu art. 5 k.p.c. nie można jednak wyprowadzać wniosku, że sąd powinien również przestrzegać strony przed lekkomyślnym nietroszczeniem się o ich własne interesy i zalecać takie działania, które każdy dorosły i zapobiegliwy człowiek podejmuje z własnej inicjatywy w swoich życiowych sprawach w oparciu o własne doświadczenie życiowe ${ }^{42}$.

Skorzystanie przez sąd z uprawnienia do udzielania pouczeń powinno być zatem dokonywane każdorazowo w odniesieniu do okoliczności konkretnej sprawy z uwzględnieniem zobiektywizowanych kryteriów ${ }^{43}$. Instytucja pouczeń została bowiem uregulowana jako dyskrecjonalna czynność sądu podejmowana z urzędu, która pozostawia kwestię oceny jej dokonania w gestii organu procesowego ${ }^{44}$. Takie

${ }^{37}$ M. Sawczuk, Niezawisłość sędziowska ..., s. 41, 42; idem, Problem aktywności stron (,,vigilantibus iura scripta sunt”) w postępowaniu cywilnym, „Zeszyty Naukowe Uniwersytetu Jagiellońskiego” 1974, z. 1, s. 116.

${ }^{38}$ Idem, Niezawistość sędziowska..., s. 42; P. Bodio, Strona słabsza, [w:] Wielka encyklopedia prawa, red. E. Smoktunowicz, C. Kosikowski, M. Sawczuk, Warszawa-Białystok 2000, s. 980; E. Wengerek, Zasada równości stron w procesie cywilnym, „Państwo i Prawo” 1955, z. 11, s. 796; A. Łazarska, op. cit., s. 438-439, 441; J. Bodio, W.J. Graliński, Znaczenie zasady równouprawnienia stron w procesie cywilnym, „Studia Iuridica Lublinensia” 2016, nr 1, DOI: http://dx.doi.org/10.17951/sil.2016.25.1.251, s. 259-260.

39 E. Wengerek, op. cit., s. 778 i n. (podaję za: T. Zembrzuski, op. cit., s. 846).

${ }^{40}$ P. Osowy, op. cit., s. 118.

${ }^{41}$ Wyrok SA w Łodzi z dnia 24 listopada 2015 r., III AUa 761/15, LEX nr 1950528.

42 Postanowienie SN z dnia 23 czerwca 1981 r., IV PZ 35/81, LEX nr 8336.

${ }^{43}$ P. Rylski, Działanie saqdu ..., s. 232.

44 T. Pietrzykowski, B. Wojciechowski, Równość, prawda i sprawiedliwość w procesie cywilnym. Rozważania na tle nowelizacji k.p.c., „Palestra” 2004, nr 9-10, s. 13-14 (podaję za: P. Rylski, Działanie $s a ̨ d u$..., s. 231). W doktrynie wskazano jednak, że sformułowanie „sąd może udzielić [...] niezbędnych 
ukształtowanie pouczeń nie wyklucza inicjatywy stron, które mogą zwrócić uwage sądowi na istnienie takiej potrzeby lub też wnosić o udzielenie pouczenia. O udzielenie pouczenia może wnioskować także przeciwnik strony wymagającej pouczenia, zwłaszcza gdy niezrozumienie zasad rządzących tokiem procesu czy skutków podejmowanych czynności procesowych utrudnia jego sprawne prowadzenie ${ }^{45}$.

Ustawodawca za pomocą art. 5 k.p.c. wprowadza więc rozwiązania służące wzmocnieniu pozycji procesowej podmiotów, które nie posiadając odpowiedniej wiedzy, mogą czuć się zagubione w zawiłościach prawa. Pouczenia sądu powinny nie tylko ułatwiać takim osobom podejmowanie właściwych decyzji i prawidłowe dokonywanie czynności procesowych, lecz także służyć usprawnianiu prowadzonego postępowania sądowego ${ }^{46}$. Pogląd ten jest aktualny zwłaszcza w kontekście nowelizacji Kodeksu postępowania cywilnego z dnia 4 lipca 2019 r. ${ }^{47}$, która wprowadziła m.in. nowe zasady związane z przygotowaniem rozprawy sądowej oraz dokonała zmiany koncentracji materiału procesowego. Formalistyczne mechanizmy w zakresie koncentracji materiału procesowego i istotne zaostrzenie rygorów dotyczących gromadzenia materiału procesowego w sprawie, w tym możliwość pominięcia przez sąd spóźnionych twierdzeń i dowodów prezentowanych przez strony oraz wzmocnienie zasady kontradyktoryjności postępowania i rozwinięcie koncepcji ciężaru wspierania przez strony postępowania, wymuszają wzmożoną aktywność i fachowość działania stron $^{48}$, co może powodować utrudnienia dla strony nieporadnej i niereprezentowanej przez profesjonalnego pełnomocnika. Dlatego sąd, realizując zasadę równości stron, powinien przykładać większą wagę do możliwości udzielania takim stronom pouczeń, pamiętając jednocześnie, że zadaniem sądu nie jest zastępowanie fachowego pełnomocnika i działanie za stronę. Pomoc sądu udzielana stronie nieporadnej i niereprezentowanej przez profesjonalnego pełnomocnika powinna ograniczać się do niezbędnych pouczeń dotyczących konieczności dokonywania stosownych czynności procesowych, powinnością sądu jest bowiem bezstronne rozpoznanie sprawy, a nie pełnienie roli pełnomocnika strony ${ }^{49}$.

pouczeń" nie oznacza całkowitej dowolności sądu w tym zakresie. Jeżeli ocena sytuacji procesowej doprowadzi do wniosku, że zachodzi niezbędna potrzeba, to możliwość pouczenia staje się w istocie powinnością sądu. Zob. M. Manowska, op. cit., s. 5; A. Marciniak, op. cit., art. 5, Nb 3; M. Uliasz, op. cit., art. $5, \mathrm{Nb} 4$.

45 A. Góra-Błaszczykowska, [w:] Kodeks postępowania cywilnego ..., art. 5, Nb 4.

46 T. Zembrzuski, op. cit., s. 862-864.

47 Ustawa z dnia 4 lipca 2019 r. o zmianie ustawy - Kodeks postępowania cywilnego oraz niektórych innych ustaw (Dz.U. 2019, poz. 1469).

${ }^{48}$ T. Ereciński, Kilka refleksji o przymusie adwokacko-radcowskim, [w:] XX lat samorzadu radców prawnych 1982-2002. Księga jubileuszowa, red. J. Żuławski, Warszawa 2002, s. 61; opinia RPO z dnia 3 sierpnia 2004 r., 36547, RPO-481256-IV/04/BB.

${ }^{49}$ M. Jaślikowski, Wyłaczenia podmiotowe spod przymusu adwokacko-radcowskiego w postępowaniu cywilnym, [w:] Aurea praxis. Aurea theoria. Księga pamiatkowa ku czci Profesora Tadeusza Erecińskiego, red. J. Gudowski, K. Weitz, t. 1, Warszawa 2011, s. 303. 


\section{BIBLIOGRAFIA}

\section{Literatura}

Błaszczak Ł., Wadliwość czynności procesowych stron i uczestników. Obecny model i propozycja zmian w przyszłym Kodeksie postępowania cywilnego, [w:] Postępowanie rozpoznawcze w przysztym Kodeksie postępowania cywilnego. Materiały Ogólnopolskiego Zjazdu Katedr i Zakładów Postępowania Cywilnego w Katowicach-Kocierzu (26-29 września 2013 r.), red. K. Markiewicz, A. Torbus, Warszawa 2014.

Błaszczak Ł., Marszałkowska-Krześ E., Przymioty procesowe stron i uczestników postępowania nieprocesowego niezbędne do dochodzenia ochrony prawnej na drodze sądowej. Wybrane zagadnienia, „Studia Prawno-Ekonomiczne” 2015, t. 95.

Bodio J., [w:] Kodeks postępowania cywilnego. Komentarz do zmian 2019, t. 1: Koszty sadowe w sprawach cywilnych. Dochodzenie roszczeń w postępowaniu grupowym. Przepisy przejściowe, red. T. Zembrzuski, Warszawa 2020.

Bodio J., Status dziecka jako uczestnika postępowania nieprocesowego, Warszawa 2019.

Bodio J., Graliński W.J., Znaczenie zasady równouprawnienia stron w procesie cywilnym, „Studia Iuridica Lublinensia” 2016, nr 1, DOI: http://dx.doi.org/10.17951/sil.2016.25.1.251.

Bodio P., Strona słabsza, [w:] Wielka encyklopedia prawa, red. E. Smoktunowicz, C. Kosikowski, M. Sawczuk, Warszawa-Białystok 2000.

Cieśliński M.M., W kwestii stosowania art. 5 k.p.c., „Przegląd Sądowy” 1999, nr 4.

Dalka S., Rola i zadania art. 5 k.p.c., „Przegląd Prawa Egzekucyjnego” 2005, nr 7-9.

Derlatka J., Wyłaczenie sędziego w postępowaniu cywilnym, Warszawa 2016.

Dobrzański B., Glosa do orzeczenia SN z dnia 20.01.1966 r., II PR 37/65, „Nowe Prawo” 1966, nr 11.

Dolecki H., [w:] Kodeks postępowania cywilnego. Komentarz, t. 1: Artykuły 1-366, red. H. Dolecki, T. Wiśniewski, LEX/el. 2013.

Ereciński T., Kilka refleksji o przymusie adwokacko-radcowskim, [w:] XX lat samorządu radców prawnych 1982-2002. Księga jubileuszowa, red. J. Żuławski, Warszawa 2002.

Ereciński T., Weitz K., Prawda i równość stron w postępowaniu cywilnym a orzecznictwo Trybunału Konstytucyjnego, [w:] Orzecznictwo Trybunału Konstytucyjnego a Kodeks postępowania cywilnego. Materiały Ogólnopolskiego Zjazdu Katedr i Zakładów Postępowania Cywilnego. Serock k. Warszawy, 24-26 września 2009 r., red. T. Ereciński, K. Weitz, Warszawa 2010.

Feliga P., [w:] Kodeks postepowania cywilnego. Komentarz, t. 1: Art. 1-505 $5^{39}$, red. T. Szanciło, Legalis 2019.

Góra-Błaszczykowska A., [w:] Kodeks postępowania cywilnego, t. I A: Komentarz. Art. 1-424 $4^{12}$, red. A. Góra-Błaszczykowska, Legalis 2020.

Góra-Błaszczykowska A., Zasada równości stron w aspekcie zmiany przepisów art. 5 i 212 k.p.c. $i$ wynikających z nich obowiązków sądu w postępowaniu cywilnym (uwagi na tle orzecznictwa Sądu Najwyższego), „Przegląd Sądowy” 2005, nr 10.

Góra-Błaszczykowska A., Zasada równości stron w procesie cywilnym, Warszawa 2008.

Harla A.G., Udzielanie przez sąd stronom i uczestnikom postępowania cywilnego wskazówek w świetle art. 5 k.p.c. (uwagi de lege lata $i$ de lege ferenda), „Przegląd Sądowy” 2003, nr 10.

Jaślikowski M., Wyłaczenia podmiotowe spod przymusu adwokacko-radcowskiego w posteppowaniu cywilnym, [w:] Aurea praxis. Aurea theoria. Ksiega pamiatkowa ku czci Profesora Tadeusza Erecińskiego, red. J. Gudowski, K. Weitz, t. 1, Warszawa 2011.

Łazarska A., Rzetelny proces cywilny, Warszawa 2012.

Manowska M., Zmiany w kodeksie postepowania cywilnego wprowadzone w 2004 r., „Przegląd Sądowy" 2005, nr 4. 
Marciniak A., [w:] Kodeks postępowania cywilnego, t. 1: Komentarz. Art. 1-205, red. A. Marciniak, Legalis 2019.

Misztal-Konecka J., O udziale w postępowaniu cywilnym osób, które doznaja przeszkód w osobistym dokonywaniu czynności procesowych, „Przegląd Sądowy” 2017, nr 11-12.

Mokry J., Aktywność informacyjna sądu a realizacja praw i obowiązków procesowych przez strony procesu cywilnego, [w:] Proces i prawo. Rozprawy prawnicze. Księga pamiątkowa ku czci Profesora Jerzego Jodłowskiego, Wrocław 1989.

Opinia RPO z dnia 3 sierpnia 2004 r., 36547, RPO-481256-IV/04/BB.

Osowy P., Aktywność informacyjna sądu a ustawowe granice pomocy stronie - rozważania na tle art. 5 k.p.c., „Rejent” 2003, nr 7-8.

Pietrzkowski H., Czynności procesowe zawodowego petnomocnika w sprawach cywilnych, Warszawa 2017.

Pietrzykowski T., Wojciechowski B., Równość, prawda i sprawiedliwość w procesie cywilnym. Rozważania na tle nowelizacji k.p.c., „Palestra” 2004, nr 9-10.

Pogonowski P., Realizacja prawa do sadu w postepowaniu cywilnym, Warszawa 2005.

Rylski P., Działanie sądu z urzędu a podstawa faktyczna wyroku cywilnego, Warszawa 2009.

Rylski P., Uczestnik postępowania nieprocesowego - zagadnienia konstrukcyjne, Warszawa 2017.

Sawczuk M., Niezawistość sędziowska a granice pomocy stronie, [w:] Studia z procesu cywilnego, red. K. Korzan, Katowice 1986.

Sawczuk M., Problem aktywności stron (,, vigilantibus iura scripta sunt”) w postęopowaniu cywilnym, „Zeszyty Naukowe Uniwersytetu Jagiellońskiego” 1974, z. 1.

Studzińska J., Prawo czy konieczność posiadania petnomocnika profesjonalnego dla ochrony strony stabszej w postępowaniu cywilnym. Kilka uwag praktycznych, [w:] Ochrona strony stabszej stosunku prawnego. Ksiega jubileuszowa ofiarowana Profesorowi Adamowi Zielińskiemu, red. M. Boratyńska, Warszawa 2016.

Uliasz M., Kodeks postepowania cywilnego. Komentarz, Legalis 2008.

Wengerek E., Zasada równości stron w procesie cywilnym, „Państwo i Prawo” 1955, z. 11.

Zembrzuski T., Pouczanie strony wystepujacej w procesie cywilnym bez zawodowego petnomocnika co do wnoszenia środków zaskarżenia, [w:] Ochrona strony słabszej stosunku prawnego. Księga jubileuszowa ofiarowana Profesorowi Adamowi Zielińskiemu, red. M. Boratyńska, Warszawa 2016.

\section{Akty prawne}

Ustawa z dnia 17 listopada 1964 r. - Kodeks postępowania cywilnego (t.j. Dz.U. 2019, poz. 1460). Ustawa z dnia 4 lipca 2019 r. o zmianie ustawy - Kodeks postępowania cywilnego oraz niektórych innych ustaw (Dz.U. 2019, poz. 1469).

\section{Orzecznictwo}

Postanowienie SN z dnia 23 czerwca 1981 r., IV PZ 35/81, LEX nr 8336.

Postanowienie SN z dnia 28 września 1999 r., II CKN 269/99, LEX nr 39112.

Postanowienie SN z dnia 2 lipca 2009 r., V CSK 481/08, LEX nr 627260.

Postanowienie SN z dnia 10 stycznia 2012 r., I UK 289/11, LEX nr 1215783.

Postanowienie SN z dnia 27 września 2012 r., III CSK 13/12, LEX nr 1224681.

Postanowienie SN z dnia 27 czerwca 2013 r., III CZ 33/13, LEX nr 1360264.

Postanowienie SN z dnia 15 stycznia 2019 r., II UZ 35/18, Legalis nr 1865721.

Postanowienie SN z dnia 24 stycznia 2019 r., I UK 5/18, Legalis nr 1866676. 
Pobrane z czasopisma Studia Iuridica Lublinensia http://studiaiuridica.umes.pl Data: 26/04/2023 07:15:13

Warunki udzielania przez sąd pouczeń na podstawie art. 5 k.p.c. Glosa do wyroku...

Wyrok SA w Warszawie z dnia 6 listopada 2012 r., I ACa 510/12, LEX nr 124693.

Wyrok SA w Warszawie z dnia 24 stycznia 2014 r., VI ACa 1240/13, LEX nr 1506315.

Wyrok SA w Katowicach z dnia 22 kwietnia 2015 r., V ACa 762/14, LEX nr 1682851.

Wyrok SA w Łodzi z dnia 24 listopada 2015 r., III AUa 761/15, LEX nr 1950528.

Wyrok SA w Gdańsku z dnia 2 lutego 2016 r., III AUa 1457/15, LEX nr 2012865.

Wyrok SA w Lublinie z dnia 30 marca 2017 r., III AUa 1115/16, LEX nr 2274274.

Wyrok SA w Gdańsku z dnia 22 marca 2018 r., III AUa 1402/17, LEX nr 2514384.

Wyrok SN z dnia 13 maja 1997 r., II UKN 100/97, OSNP 1998, nr 4, poz. 133.

Wyrok SN z dnia 16 września 1998 r., II UKN 214/98, OSNP 1999, nr 18, poz. 593.

Wyrok SN z dnia 30 czerwca 1999 r., II UKN 21/99, OSNAP 2000, nr 18, poz. 695.

Wyrok SN z dnia 13 lipca 2000 r., II UKN 639/99, OSNP 2000, nr 3, poz. 78.

Wyrok SN z dnia 3 sierpnia 2006 r., II UK 258/05, Legalis nr 303358.

Wyrok SN z dnia 18 sierpnia 2009 r., I UK 74/09, LEX nr 530693.

Wyrok SN z dnia 30 czerwca 2010 r., V CSK 1/10, LEX nr 677906.

Wyrok SN z dnia 11 czerwca 2013 r., II UK 389/12, OSNP 2014, nr 3, poz. 48.

Wyrok SN z dnia 11 października 2013 r., III UK 139/12, LEX nr 1463907.

Wyrok SN z dnia 27 lutego 2014 r., II PK 134/13, LEX nr 1455113.

Wyrok SN z dnia 4 kwietnia 2014 r., I UK 363/13, LEX nr 1482341.

Wyrok SN z dnia 6 kwietnia 2017 r., II UK 112/16, LEX nr 2298299.

Wyrok SN z dnia 21 marca 2018 r., II UK 231/17, LEX nr 2490054.

Wyrok SN z dnia 17 kwietnia 2018 r., I PK 30/17, LEX nr 2558421.

Wyrok SN z dnia 27 lutego 2019 r., II PK 307/17, LEX nr 2626246.

\section{SUMMARY}

The author agrees with the Supreme Court's opinion that giving instructions by the court referred to in Article 5 of the Code of Civil Procedure should be exceptional and depend on judgement and recognition of court credited with a specific procedural situation. Giving instructions by the court is determined by justified need and necessary nature of instructions. It can take place when there is a need to prevent inequality of subjects of pending proceedings in the context of the principle of equality of parties, i.e. when a party, due to its clumsiness and complexity of the case, is not able to understand the essence of proceedings or take appropriate procedural steps.

Keywords: giving instructions by the court; justified procedural need; principles of equality of parties 